\title{
Seroprevalence of Dengue and Chikungunya Virus Antibodies, French Polynesia, 2014-2015
}

\section{Maite Aubry, Anita Teissier, Michael Huart, Sébastien Merceron, Jessica Vanhomwegen, Mihiau Mapotoeke, Teheipuaura Mariteragi-Helle, Claudine Roche, Anne-Laure Vial, Sylvianne Teururai, Sébastien Sicard, Sylvie Paulous, Philippe Desprès, Jean-Claude Manuguerra, Henri-Pierre Mallet, Allison Imrie, Didier Musso, Xavier Deparis, Van-Mai Cao-Lormeau}

We investigated dengue and chikungunya virus antibody seroprevalence in French Polynesia during 2014-2015. Dengue virus seroprevalence was $\approx 60 \%$ among schoolchildren and $>83 \%$ among the general population; chikungunya virus seroprevalence was $<3 \%$ before and $76 \%$ after Zika virus emergence (2013). Dengue virus herd immunity may affect Zika virus infection and pathogenesis.

$\mathrm{I}$ n French Polynesia, the only recognized actively circulating arboviruses were the 4 dengue viruses (DENV; family Flaviviridae, genus Flavivirus) $(1,2)$ until Zika virus (family Flaviviridae, genus Flavivirus) emerged there in 2013 (3), followed by chikungunya virus (family

Author affiliations: Aix Marseille University, IRD, AP-HM, SSA, VITROME, IHU-Méditerranée Infection, Marseille, France (M. Aubry, A. Teissier, T. Mariteragi-Helle, S. Teururai, D. Musso, V.-M. Cao-Lormeau); Institut Louis Malardé, Papeete, French Polynesia (M. Aubry, A. Teissier, M. Mapotoeke, T. Mariteragi-Helle,

C. Roche, S. Teururai, D. Musso, V.-M. Cao-Lormeau);

Centre d'Épidémiologie et de Santé Publique des Armées, Marseille, France, and Unité Mixte de Recherche Sciences Economiques et Sociales de la Santé et Traitement de I'Information Médicale, Marseille (M. Huart, S. Sicard, X. Deparis); Institut de la Statistique de la Polynésie Française, Papeete, and Institut National de la Statistique et des Études Économiques, Sainte Clotilde, La Réunion (S. Merceron); Institut Pasteur, Paris, France (J. Vanhomwegen, S. Paulous, J.-C. Manuguerra); Direction de la Santé de la Polynésie Française, Papeete (M. Mapotoeke, A.-L. Vial, H.-P. Mallet); Direction Départementale de la Cohésion Sociale et de la Protection des Populations, Yonne, France (A.-L. Vial); Université de la Réunion, Sainte Clotilde (P. Desprès); University of Western Australia, Perth, Western Australia, Australia (A. Imrie)

DOI: https://doi.org/10.3201/eid2403.171149
Togaviridae, genus Alphavirus) in 2014 (4). Serosurveys conducted among blood donors in French Polynesia during 2011-2013, before these outbreaks, confirmed the absence of Zika and chikungunya virus circulation and assessed DENV antibody seroprevalence at $\approx 80 \%$ at that time $(5,6)$. Another study conducted after the emergence of Zika virus showed Zika virus antibody seroprevalence rates $\pm 95 \%$ CIs to be $49 \% \pm 7 \%$ among the general population and $66 \%$ $\pm 5 \%$ among schoolchildren in 2014 and $22 \% \pm 6 \%$ among the general population in 2015 (7). We report seroprevalence of antibodies against the 4 DENVs and chikungunya virus in French Polynesia in 2014-2015 and discuss the possible role of anti-DENV herd immunity on Zika virus infection and pathogenesis.

\section{The Study}

To assess antibody seroprevalence against DENV types 1-4 and chikungunya virus in the population of French Polynesia, we conducted 3 cluster samplings (7). During February-March 2014, we sampled 196 participants from the general population of the 8 most inhabited islands of the 5 French Polynesia archipelagos: Tahiti and Moorea (Society), Rangiroa and Makemo (Tuamotu), Nuku Hiva and Hiva Oa (Marquesas), Rurutu (Australs), and Rikitea (Gambier). To better estimate seroprevalence of antibodies against these viruses among children, during MayJune 2014, we recruited 476 schoolchildren from primary and high schools on the most populous island (Tahiti). To increase accuracy of seroprevalence data for DENVs and assess postoutbreak chikungunya virus seroprevalence, during September-November 2015, we sampled 700 members of the general population from the most inhabited archipelago (Society). All participants were asked whether they had had symptoms suggestive of past dengue disease. Because chikungunya virus emerged in French Polynesia in late 2014, symptoms suggestive of past disease were recorded only from participants sampled in 2015. The study was conducted in accordance with the French Polynesia Ethics Committee (agreement 60/CEPF_06/27/2013).

We performed detection of DENV and chikungunya virus IgG on blood samples collected in 2014 by using a recombinant-antigen-based indirect ELISA $(5,6)$ and tested samples collected in 2015 by microsphere 
immunoassay (MIA) (8) using the same recombinant antigens as for the ELISA. Among the samples collected in 2015 , we selected 20 to be a representative panel of the different antibody profiles found by MIA and tested them for neutralizing antibodies against each dengue, chikungunya, and Zika virus (8). We analyzed data by using GraphPad Prism version 6.03 software (https://www.graphpad.com/) and the Fisher exact test. We set significance at $\mathrm{p}<0.05$.

Overall seropositivity rates for antibodies against $\geq 1$ DENV were $96 \% \pm 3 \%$ among the general population and $60 \% \pm 5 \%$ among schoolchildren in 2014 and $83 \%$ $\pm 3 \%$ among the general population in 2015 (Table 1). Seroprevalence of DENV antibodies did not differ significantly between archipelagos, except for DENV-3, which differed between Society $(76 \% \pm 18 \%)$ and Austral-Gambier $(53 \% \pm 15 \%)$ Islands $(\mathrm{p}=0.034)$. In all 3 groups of participants, we found the highest seropositivity rates for DENV-1 antibodies and the lowest for DENV-2. Seropositivity rates in 2014 and 2015 for all DENV antibodies were significantly lower for schoolchildren (median age 11 years) than for the general population (median age 41 years in 2014 and 43 years in 2015) (all $p<0.0001)$. Seroprevalence of chikungunya virus antibodies was $3 \% \pm$ $3 \%$ among the general population and $1 \% \pm 1 \%$ among schoolchildren in 2014 and $76 \% \pm 5 \%$ among the general population in 2015 after the outbreak.

According to information provided by a questionnaire, the percentages of asymptomatic DENV infections were $65 \% \pm 7 \%$ among the general population and $81 \% \pm$ $5 \%$ among schoolchildren in 2014 and 51\% $\pm 4 \%$ among the general population in 2015 . The percentage of asymptomatic chikungunya virus infections in participants recruited in 2015 was $13 \% \pm 2 \%$. Among the 20 samples positive by MIA for IgG against DENV-1-4 and chikungunya virus in this study and against Zika virus in the previous serosurvey (7), the proportions showing neutralizing activity were 8/9 (89\%) for DENV-1, $5 / 5$ (100\%) for DENV-2, 6/6 (100\%) for DENV-3, 6/6 (100\%) for DENV-4, and 7/8 (88\%) each for chikungunya and Zika viruses (Table 2).

\section{Conclusions}

The finding of DENV IgG in $>80 \%$ of the general population sampled in 2014 and 2015 corroborates past high transmission rates for these viruses in French Polynesia $(1,2,6,9)$. The lower seropositivity rates for antibodies against DENVs among children is consistent with seroprevalence rates for antibodies against viruses endemic to the region, which are expected to increase with duration of exposure (6). Finding the highest seroprevalence rate against DENV-1 in the general population and schoolchildren is consistent with the long-term circulation of this virus in French Polynesia during 2001-2009 and since $2013(1,9)$. DENV-2 has not circulated in French Polynesia since $2000(9)$, which is consistent with the lowest seroprevalence rate against this virus. The reduced population immunity against DENV-2 coupled with the circulation of this virus in neighboring Pacific Islands and detection of imported infections in travelers entering French Polynesia from Vanuatu in February 2017 (9) indicates that French Polynesia is at risk for a new epidemic. Although seroprevalence rates for antibodies against DENVs are consistent with epidemiologic data, bias associated with the presence of cross-reactive antibodies produced during a previous flavivirus infection could have resulted in detection of antibodies against viruses to which the persons were never exposed. The proportion of asymptomatic DENV infections assessed in this study seems to be consistent with reported rates (10). However, because the questionnaire asked about clinical manifestations suggestive of past DENV infection over a lifetime or during time spent in French Polynesia, the estimates may be strongly limited by recall bias.

The low seroprevalence rates for chikungunya virus antibodies for the general population $(3 \% \pm 3 \%)$ and

Table 1. Seropositivity for antibodies against dengue and chikungunya viruses among participants randomly recruited, French Polynesia, 2014-2015*

\begin{tabular}{|c|c|c|c|c|c|c|c|}
\hline \multirow[b]{3}{*}{ Virus } & \multicolumn{7}{|c|}{ Seropositivity, no. $(\% \pm 95 \% \mathrm{Cl})$} \\
\hline & \multicolumn{5}{|c|}{ General population, Feb-Mar 2014} & \multirow{2}{*}{$\begin{array}{l}\text { Schoolchildren, } \\
\text { May-Jun 2014, } \\
\text { Society, } n=476\end{array}$} & \multirow{2}{*}{$\begin{array}{l}\text { General population } \\
\text { Sep-Nov } 2015, \\
\text { Society, } n=700\end{array}$} \\
\hline & $\begin{array}{c}\text { Society, } \\
\mathrm{n}=49\end{array}$ & $\begin{array}{l}\text { Tuamotu, } \\
\mathrm{n}=49\end{array}$ & $\begin{array}{c}\text { Marquesas, } \\
\mathrm{n}=49\end{array}$ & $\begin{array}{c}\text { Austral - } \\
\text { Gambier, } n=49\end{array}$ & $\begin{array}{c}\text { Total, } \\
\mathrm{n}=196\end{array}$ & & \\
\hline \multicolumn{8}{|l|}{ Dengue } \\
\hline$\geq 1$ type & $46(94 \pm 8)$ & $49(100 \pm 0)$ & $46(94 \pm 8)$ & $47(96 \pm 6)$ & $188(96 \pm 3)$ & $285(60 \pm 5)$ & $582(83 \pm 3)$ \\
\hline Type 1 & $42(86 \pm 16)$ & $47(96 \pm 5)$ & $41(84 \pm 13)$ & $42(86 \pm 11)$ & $172(88 \pm 6)$ & $239(50 \pm 5)$ & $562(80 \pm 4)$ \\
\hline Type 2 & $23(47 \pm 17)$ & $22(45 \pm 13)$ & $26(53 \pm 12)$ & $28(57 \pm 12)$ & $99(51 \pm 7)^{\prime}$ & 0 & $127(18 \pm 4)$ \\
\hline Type 3 & $37(76 \pm 18)$ & $33(67 \pm 21)$ & $35(71 \pm 14)$ & $26(53 \pm 15)$ & $131(67 \pm 9)$ & $72(15 \pm 3)$ & $384(55 \pm 4)$ \\
\hline Type 4 & $31(63 \pm 8)$ & $32(65 \pm 21)$ & $29(59 \pm 15)$ & $27(55 \pm 15)$ & $119(61 \pm 8)$ & $69(14 \pm 3)$ & $293(42 \pm 7)$ \\
\hline Asymptomatic & $\begin{array}{c}36 / 46 \\
(78 \pm 12)\end{array}$ & $\begin{array}{c}29 / 49 \\
(59 \pm 14)\end{array}$ & $\begin{array}{c}24 / 46 \\
(52 \pm 14)\end{array}$ & $\begin{array}{c}34 / 47 \\
(72 \pm 13)\end{array}$ & $\begin{array}{l}123 / 188 \\
(65 \pm 7)\end{array}$ & $\begin{array}{l}230 / 285 \\
(81 \pm 5)\end{array}$ & $\begin{array}{l}299 / 582 \\
(51 \pm 4)\end{array}$ \\
\hline Chikungunya & $3(6 \pm 8)$ & $1(2 \pm 4)$ & $1(2 \pm 4)$ & $1(2 \pm 4)$ & $6(3 \pm 3)$ & $2(1 \pm 1)$ & $529(76 \pm 5)$ \\
\hline Asymptomatic & ND & ND & ND & ND & ND & ND & $70 / 529(13 \pm 2)$ \\
\hline
\end{tabular}

${ }^{*} 95 \%$ Cls were calculated by taking into account the cluster sampling design and using the Fisher exact test. Median ages of participants among the general population, 38-47 y; of schoolchildren, $11 \mathrm{y}$. ND, not determined. 
Table 2. Results of microsphere immunoassay and neutralization assay for dengue, chikungunya, and Zika viruses for 20 participants sampled from the Society archipelago, French Polynesia, September-November, 2015*

\begin{tabular}{|c|c|c|c|c|c|c|c|c|c|c|c|c|c|}
\hline \multirow[b]{3}{*}{ Participant ID } & \multirow{3}{*}{$\begin{array}{c}\text { Years in } \\
\text { French } \\
\text { Polynesia }\end{array}$} & \multicolumn{12}{|c|}{ Virus } \\
\hline & & \multicolumn{2}{|c|}{ Dengue 1} & \multicolumn{2}{|c|}{ Dengue 2} & \multicolumn{2}{|c|}{ Dengue 3} & \multicolumn{2}{|c|}{ Dengue 4} & \multicolumn{2}{|c|}{ Chikungunya } & \multicolumn{2}{|c|}{ Zikał } \\
\hline & & MIA & NTA† & MIA & NTA & MIA & NTA & MIA & NTA & $\mathrm{MIA}$ & NTA & MIAf & NTA \\
\hline Pueu-6 & 1 & - & $<10$ & - & $<10$ & - & $<10$ & - & $<10$ & + & 80 & - & $<10$ \\
\hline Papeete-62 & 2 & - & $<10$ & - & $<10$ & - & $<10$ & - & $<10$ & - & $<10$ & - & 10 \\
\hline Papeete-63 & 2 & - & $<10$ & - & $<10$ & - & $<10$ & - & $<10$ & - & $<10$ & - & 40 \\
\hline Papeete-35 & 6 & - & $<10$ & - & $<10$ & - & $<10$ & - & $<10$ & - & $<10$ & - & 20 \\
\hline Punaauia-96 & 6 & - & $<10$ & - & $<10$ & - & $<10$ & - & $<10$ & - & $<10$ & - & 10 \\
\hline Pirae-6 & 10 & - & $<10$ & - & $<10$ & - & $<10$ & - & 80 & - & $<10$ & + & 160 \\
\hline Mahina-26 & 13 & - & $<10$ & - & $<10$ & - & $<10$ & - & $<10$ & + & 320 & + & 160 \\
\hline Punaauia-61 & 15 & - & 640 & - & $<10$ & - & $<10$ & - & $<10$ & - & $<10$ & - & $<10$ \\
\hline Faaa-54 & 17 & + & 10 & - & $<10$ & - & $<10$ & - & $<10$ & + & 160 & + & $>1,280$ \\
\hline Toahotu-1 & 18 & - & $<10$ & - & $<10$ & - & $<10$ & + & 80 & - & $<10$ & - & $<10$ \\
\hline Punaauia-93 & 21 & - & $<10$ & - & 640 & - & $<10$ & - & $<10$ & - & $<10$ & - & 20 \\
\hline Punaauia-36 & 24 & - & 40 & - & 640 & - & 40 & - & 80 & + & 160 & - & 20 \\
\hline Papenoo-10 & 28 & + & 640 & + & $>1,280$ & + & $>1,280$ & + & 640 & - & $<10$ & - & $<10$ \\
\hline Moorea-59 & 36 & + & 320 & - & $<10$ & + & $>1,280$ & + & $>1,280$ & - & $<10$ & + & 640 \\
\hline Paea-48 & 38 & + & 160 & - & $<10$ & - & 80 & - & 80 & - & $<10$ & + & 160 \\
\hline Papeari-17 & 44 & + & 320 & + & $>1,280$ & + & 80 & + & 160 & + & 20 & + & 320 \\
\hline Papenoo-1 & 49 & + & 160 & + & $>1,280$ & + & 20 & + & 80 & + & 640 & + & $<10$ \\
\hline Faaa-22 & 54 & + & 80 & + & 640 & - & 320 & - & 160 & + & 40 & - & $<10$ \\
\hline Papeete-10 & 55 & + & 320 & + & $>1,280$ & + & 80 & + & 640 & + & $<10$ & + & 160 \\
\hline Afaahiti-7 & 67 & + & 80 & - & 640 & + & 320 & - & 160 & - & $<10$ & - & $<10$ \\
\hline
\end{tabular}

schoolchildren $(1 \% \pm 1 \%)$ in 2014 corroborate previous findings for blood donors sampled during 2011-2013 (3\%) (5), suggesting that this virus did not actively circulate in French Polynesia before 2014. The seroprevalence rate for the general population in $2015(76 \% \pm 5 \%)$ was higher than the initial estimate of $25 \%$ of chikungunya virus infections, which was based on the number of patients who sought medical care during the outbreak (5). The rate of asymptomatic chikungunya virus infections identified in this study $(13 \% \pm 2 \%)$ was comparable to rates reported by other countries (10).

Chikungunya virus antibody seroprevalence was much higher $(76 \% \pm 5 \%)$ than Zika virus antibody seroprevalence for the general population in $2015(22 \% \pm$ $6 \%$ ) (7), despite the fact that both were virgin soil outbreaks occurring at the same place during 2 consecutive years $(5,6)$. This discrepancy could be the result of distinct vector competence for Zika and chikungunya viruses in French Polynesia, as demonstrated in local mosquito species $(11,12)$. Another possible explanation is that past exposure of the population to dengue viruses, as corroborated by the high level of anti-DENV neutralizing responses detected in samples collected in 2015, may have provided cross-protection against Zika virus infection (13). However, the occurrence of many cases of GuillainBarré syndrome and Zika virus infection-associated congenital abnormalities $(8,14)$ might also suggest that Zika virus immunopathogenesis is enhanced in the setting of high seroprevalence of DENV antibodies (15).

\section{Acknowledgments}

We are grateful to Rémy Michel for his participation in the development of the sampling protocols and to Eliane Mama, Sylvia Fontanel, and Jean-Paul Pescheux for their help collecting blood samples. We also thank the staff from the Ministries of Health and Education of French Polynesia and from the municipalities selected for the study for their support in recruiting participants and collecting blood samples. We especially thank everyone who volunteered in this study.

This study received grants from the Contrat de Projet Etat-Pays (convention no. 7331/MSS/DSP du 31/08/12 modifiée) and from the French Government Investissement d'Avenir Programme (Labex Integrative Biology of Emerging Infectious Diseases grant no. ANR-10-LABX-62-IBEID).

\section{About the Author}

Dr. Aubry is a research scientist at the Institut Louis Malardé, Tahiti, French Polynesia. Her research focuses on the epidemiology in the Pacific region and genetic evolution of various arboviruses, including dengue, Zika, chikungunya, and Ross River viruses.

\section{References}

1. Singh N, Kiedrzynski T, Lepers C, Benyon EK. Dengue in the Pacific - an update of the current situation. Pac Health Dialog. 2005;12:111-9.

2. Cao-Lormeau V-M, Roche C, Musso D, Mallet H-P, Dalipanda T, Dofai A, et al. Dengue virus type 3, South Pacific islands, 2013. Emerg Infect Dis. 2014;20:1034-6. http://dx.doi.org/10.3201/ eid2006.131413 
3. Cao-Lormeau V-M, Roche C, Teissier A, Robin E, Berry A-L, Mallet H-P, et al. Zika virus, French Polynesia, South Pacific, 2013. Emerg Infect Dis. 2014;20:1085-6. http://dx.doi.org/10.3201/ eid2006.140138

4. Aubry M, Teissier A, Roche C, Richard V, Yan AS, Zisou K, et al. Chikungunya outbreak, French Polynesia, 2014. Emerg Infect Dis. 2015;21:724-6. http://dx.doi.org/10.3201/ eid2104.141741

5. Aubry M, Finke J, Teissier A, Roche C, Broult J, Paulous S, et al. Silent circulation of Ross River virus in French Polynesia. Int J Infect Dis. 2015;37:19-24. http://dx.doi.org/10.1016/ j.ijid.2015.06.005

6. Aubry M, Finke J, Teissier A, Roche C, Broult J, Paulous S, et al. Seroprevalence of arboviruses among blood donors in French Polynesia, 2011-2013. Int J Infect Dis. 2015;41:11-2. http://dx.doi.org/10.1016/j.ijid.2015.10.005

7. Aubry M, Teissier A, Huart M, Merceron S, Vanhomwegen J, Roche C, et al. Zika virus seroprevalence, French Polynesia, 2014-2015. Emerg Infect Dis. 2017;23:669-72. http://dx.doi.org/ 10.3201/eid2304.161549

8. Cao-Lormeau V-M, Blake A, Mons S, Lastère S, Roche C, Vanhomwegen J, et al. Guillain-Barré syndrome outbreak associated with Zika virus infection in French Polynesia: a case-control study. Lancet. 2016;387:1531-9. http://dx.doi.org/ 10.1016/S0140-6736(16)00562-6

9. Aubry M, Teissier Y, Mapotoeke M, Teissier A, Giard M, Musso D, et al. High risk of dengue type 2 outbreak in French Polynesia, 2017. Euro Surveill. 2017;22:30505. http://dx.doi.org/10.2807/1560-7917.ES.2017.22.14.30505e

10. Clapham HE, Cummings DAT, Johansson MA. Immune status alters the probability of apparent illness due to dengue virus infection: evidence from a pooled analysis across multiple cohort and cluster studies. PLoS Negl Trop Dis. 2017;11:e005926. http://dx.doi.org/10.1371/journal.pntd.0005926

11. Richard V, Paoaafaite T, Cao-Lormeau V-M. Vector competence of French Polynesian Aedes aegypti and Aedes polynesiensis for Zika virus. PLoS Negl Trop Dis. 2016;10:e0005024. http://dx.doi.org/10.1371/journal.pntd.0005024

12. Richard V, Paoaafaite T, Cao-Lormeau V-M. Vector competence of Aedes aegypti and Aedes polynesiensis populations from $\mathrm{F}$ rench Polynesia for chikungunya virus. PLoS Negl Trop Dis. 2016;10:e0004694. http://dx.doi.org/10.1371/ journal.pntd.0004694

13. Priyamvada L, Quicke KM, Hudson WH, Onlamoon N, Sewatanon J, Edupuganti S, et al. Human antibody responses after dengue virus infection are highly cross-reactive to Zika virus. Proc Natl Acad Sci U S A. 2016;113:7852-7. http://dx.doi.org/10.1073/ pnas. 1607931113

14. Besnard M, Eyrolle-Guignot D, Guillemette-Artur P, Lastère S, Bost-Bezeaud F, Marcelis L, et al. Congenital cerebral malformations and dysfunction in fetuses and newborns following the 2013 to 2014 Zika virus epidemic in French Polynesia. Euro Surveill. 2016;21:30181. http://dx.doi.org/10.2807/ 1560-7917.ES.2016.21.13.30181

15. Andrade DV, Harris E. Recent advances in understanding the adaptive immune response to Zika virus and the effect of previous flavivirus exposure. Virus Res. 2017 Jun 26:pii:S0168-1702(17)30462-8. Epub ahead of print. http://dx.doi.org/10.1016/j.virusres.2017.06.019

Address for correspondence: Maite Aubry, Institut Louis Malardé, PO Box 30, 98713 Papeete, Tahiti, French Polynesia; email: maubry@ilm.pf
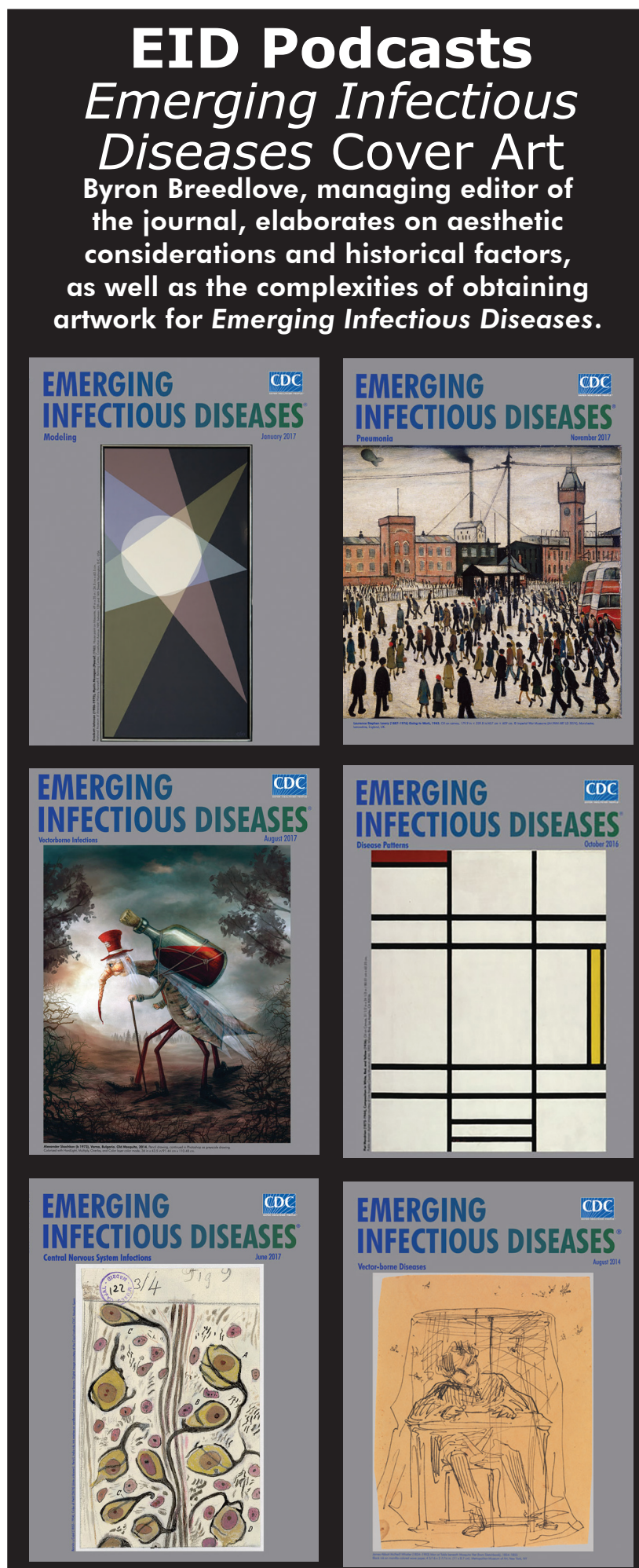

Visit our website to listen:

EMERGING INFECTIOUS DISEASES

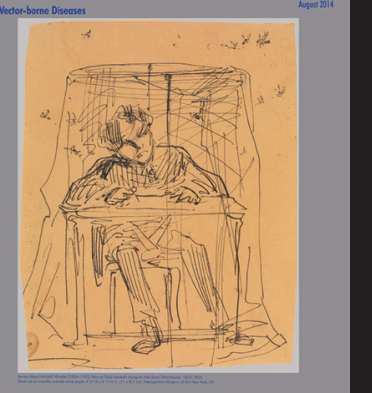

https://www2c.cdc.gov/

podcasts/player.

asp?f $=8646224$ 